\title{
Pediatric Appendicitis Management During the COVID-19 Pandemic: What Has Changed?
}

\author{
COVID-19 Pandemi Döneminde Pediyatrik Apandisit Yönetimi: Neler Değişti?
}

\author{
(D) Oktay Ulusoy, (D) Osman Zeki Karakuş, (D) Oğuz Ateş, (D) Efil Aydın, (D) Gülce Hakgüder, (D) Mustafa Olguner, (D) Feza Miraç Akgür \\ Dokuz Eylül University Faculty of Medicine, Department of Pediatric Surgery, Izmir, Turkey
}

\section{Abstract}

Introduction: The most common surgical emergency in the paediatric group during the coronavirus disease-2019 (COVID-19) pandemic is appendicitis, as it was before. This study aimed to evaluate clinical differences of paediatric appendicitis cases and changes in the management strategy between the pandemic and non-pandemic period.

Methods: Cases during the non-pandemic period (March-July 2019) and pandemic period (March-July 2020) were analysed. Demographic data, duration of symptoms, physical examination, laboratory and radiological findings, paediatric appendicitis score (PAS), operative techniques, medical treatment, complications and hospital stay were evaluated retrospectively.

Results: This study enrolled 70 patients during the non-pandemic period and 48 patients during the pandemic period. Duration of symptoms was significantly prolonged $(p<0.001)$ and PAS was significantly increased during the pandemic period $(p=0.001)$. Abdominopelvic ultrasonography detected abscess formation in one (1.4\%) patient and 10 (20.8\%) patients during the non-pandemic period and pandemic period, respectively. Complicated appendicitis was significantly higher $(p=0.025)$ and the hospital stay were significantly longer during the pandemic period ( $p=0.017$ ).

Conclusion: During the COVID-19 pandemic, fewer patients presented to the paediatric emergency department with suspected appendicitis. Complicated appendicitis cases and hospital stay increased during the same period. The COVID-19 pandemic caused some changes in our approach to paediatric appendicitis cases such as the effective use of personal protective equipment, PAS scoring system and abdominopelvic ultrasonography.

Keywords: Laparoscopic appendectomy, COVID-19, appendicitis, paediatric

\section{Öz}

Giriș: Koronavirüs hastalığı-2019 (COVID-19) pandemisi sırasında, daha önce olduğu gibi çocuk yaş grubunda en yaygın cerrahi acil durum apandisittir. Çocuk apandisit olgularının klinik farklılıklarını ve pandemi dönemi ile pandemi dışı dönem arasındaki yönetim stratejisindeki değişiklikleri değerlendirmeyi amaçladık.

Yöntemler: Pandemi dışı dönem (Mart-Temmuz 2019) ve pandemi dönemi (Mart-Temmuz 2020) analiz edildi. Demografik veriler, semptomların süresi, fizik muayene, laboratuvar ve radyolojik bulgular, çocuk apandisit skoru (PAS), ameliyat teknikleri, tıbbi tedavi, komplikasyonlar ve hastanede kalış süreleri geriye dönük olarak değerlendirildi.

Bulgular: Çalışmamızda pandemi dışı dönemde 70 hasta ve pandemi döneminde 48 hasta yer aldı. Pandemi döneminde semptomların süresi anlamlı olarak uzundu $(p<0,001)$ ve PAS anlamlı olarak yüksekti $(p=0,001)$. Abdominopelvik ultrasonografide pandemi dışı dönemde bir hastada $(\% 1,4)$, pandemi döneminde ise 10 hastada $(\% 20,8)$ apse formasyonu saptandı. Pandemi döneminde komplike apandisitin anlamlı olarak yüksek $(p=0,025)$ ve hastaların hastanede kalış sürelerinin anlamlı olarak daha uzun $(p=0,017)$ olduğu görüldü.

Sonuç: COVID-19 salgını sırasında, daha az hasta apandisit şüphesiyle çocuk acil servislerine başvurdu. Aynı dönemde komplike apandisit olguları ve hastanede kalış süreleri arttı. Çalışmamızda, COVID-19 pandemisinin, çocuk apandisit olgularına yaklaşımımızda kişisel koruyucu ekipmanların, PAS skorlama sisteminin ve abdominopelvik ultrasonografinin etkili kullanımı gibi bazı değişikliklere neden olduğunu belirledik.

Anahtar Kelimeler: Laparoskopik apendektomi, COVID-19, apandisit, çocuk 


\section{Introduction}

The novel severe acute respiratory syndrome-coronavirus-2 was first detected in December 2019, and the resultant condition is called coronavirus disease-2019 (COVID-19). ${ }^{1}$ COVID-19 has been declared as a pandemic by the World Health Organization on March 11, 2020. ${ }^{2}$ Quarantine and stay-at-home orders have been used to prevent disease dissemination, health system overload and mortality. Thus, hospital admissions and elective operations were deferred; however, non-COVID-19 emergency cases posed problems, mainly late presentation to hospitals and advanced illness. ${ }^{3}$ Thus, the incidence of intensive care unit admissions, morbidity and mortality have been increased among nonCOVID-19 emergency cases. ${ }^{3}$

The most common surgical emergency in the paediatric group during the pandemic was appendicitis, as it was before. ${ }^{4}$ We observed that paediatric appendicitis cases during the pandemic were more complicated with a prolonged duration of symptoms. Therefore, this retrospective study was carried out to evaluate clinical differences in paediatric appendicitis cases and the changes in the management strategy between the pandemic and non-pandemic periods.

\section{Materials and Methods}

The Institutional Ethics Review Board for Clinical Research approved this study (5639-GOA-2020/18-19).

The first COVID-19 case was confirmed in Turkey on March 10, 2020. Paediatric appendicitis cases occurring during the non-pandemic period (March-July 2019) and the pandemic period (March-July 2020) were analysed. Demographic data, duration of symptoms, physical examination, laboratory and radiological findings, paediatric appendicitis score (PAS), ${ }^{5}$ operative techniques, medical treatment, complications and hospital stay were evaluated retrospectively. All patients underwent abdominopelvic ultrasonography (US).

Appendicitis cases during the pandemic period were examined for respiratory symptoms, myalgia, diarrhea, smell or taste disorders and suspected contact with COVID-19 cases. All patients were evaluated preoperatively with polymerase chain reaction (PCR) analysis.

Personal protective equipment is used as standard during surgeries in all patients with or without COVID-19 during the pandemic. Laparoscopic appendectomy was the preferred operative method during both periods. Open appendectomy was preferred for complicated appendicitis with appendiceal mass that could not be separated by external manipulation under general anaesthesia, generalised peritonitis with massive abdominal distension and positive PCR analysis for COVID-19 (in the pandemic period). All laparoscopic procedures were conducted with a single-port incisionlessintracorporeal conventional equipment-endoscopic surgery (SPICES) approach. ${ }^{6}$

\section{Statistical Analysis}

Statistical analyses were performed using the commercial package SPSS for Windows version 19.0 (SPSS, Inc., Chicago, IL, USA). Numerical data fit the normal distribution; thus, the independent t-test was used for comparing the two periods. The chi-square test was used for categorical variables. Significance was accepted as $p<0.05$.

\section{Results}

This study analysed 118 patients (non-pandemic period, $\mathrm{n}=70$; pandemic period, $\mathrm{n}=48$ ) with a preliminary diagnosis of appendicitis. The mean patient age was $11.0 \pm 3.8$ years. On analysis of the histopathological evaluation results, findings of $85.7 \%$ of the cases were compatible with appendicitis during the non-pandemic period, while $89.6 \%$ of the cases were compatible with appendicitis during the pandemic period. The duration of symptoms was significantly prolonged, and patients with fever, nausea or vomiting and migration of pain were significantly increased during the pandemic period (Table 1). No significant difference in age and gender was found between the two periods.

Abdominopelvic US findings suggested appendicitis in 41 and 36 patients during the non-pandemic and pandemic periods, respectively. The abdominopelvic US had $68 \%$ sensitivity and $60 \%$ specificity during the non-pandemic period and $84 \%$ sensitivity and $40 \%$ specificity during the pandemic period. Abdominopelvic US detected abscess formation in 1 (1.4\%) patient and in 10 patients (20.8\%) during the non-pandemic and pandemic periods, respectively $(p<0.001)$. PAS $\geq 7$ was found in 45 (64.3\%) patients during the non-pandemic period and in 43 (89.6\%) patients during the pandemic period. The mean value of PAS during the pandemic period was significantly increased compared with that during the nonpandemic period $(p=0.001$ ) (Table 1 ).

Cases of complicated appendicitis were significantly high during the pandemic period (Table 2). During the non-pandemic period, while surgery was completed laparoscopically in 67 patients, it was converted to open appendectomy in 3 patients. During the pandemic period, while laparoscopic appendectomy was conducted in 38 patients, open appendectomy was performed in 10 patients and there was no conversion to open appendectomy from laparoscopy. Rates of open appendectomy was significantly higher during the pandemic period $(n=10,20.8 \%)$ than during the non-pandemic period $(n=3,4.2 \%)(p=0.005)$. 
Table 1. Demographic and clinical findings of the patients

\begin{tabular}{|c|c|c|c|}
\hline & $\begin{array}{l}\text { Non-pandemic period } \\
(n=70)\end{array}$ & $\begin{array}{l}\text { Pandemic period } \\
(n=48)\end{array}$ & $\mathbf{p}$ \\
\hline Age (years) & $11.7 \pm 3.9$ & $10.1 \pm 4.1$ & 0.058 \\
\hline Male/female (n) & $43 / 27$ & $33 / 15$ & 0.415 \\
\hline Duration of symptoms (hour)* & $22.6 \pm 23.5$ & $44.8 \pm 43.7$ & $<0.001$ \\
\hline Anorexia n (\%) & $46(65.7 \%)$ & $36(75.0 \%)$ & 0.282 \\
\hline Nausea or vomiting $\mathrm{n}(\%)$ & $46(65.7 \%)$ & $42(87.5 \%)$ & 0.008 \\
\hline Fever n (\%) & $20(28.6 \%)$ & $23(47.9 \%)$ & 0.032 \\
\hline Migration of pain $\mathrm{n}(\%)$ & $32(45.7 \%)$ & $39(81.3 \%)$ & $<0.001$ \\
\hline Right lower quadrant tenderness n (\%) & $70(100 \%)$ & $48(100 \%)$ & - \\
\hline Rebound tenderness $\mathbf{n}(\%)$ & $47(67.1 \%)$ & $38(79.2 \%)$ & 0.153 \\
\hline PAS* & $7.1 \pm 1.7$ & $8.1 \pm 1.6$ & 0.001 \\
\hline
\end{tabular}

Table 2. Pathological findings of appendicitis cases

\begin{tabular}{|llll|}
\hline & $\begin{array}{l}\text { Non-pandemic period } \\
\mathbf{n}(\%)\end{array}$ & $\begin{array}{l}\text { Pandemic period } \\
\mathbf{n}(\%)\end{array}$ & p \\
Acute appendicitis & $50(83.3 \%)$ & $27(62.8 \%)$ & 0.025 \\
Complicated appendicitis & $10(16.7 \%)$ & $16(37.2 \%)$ & \\
\hline Significance was accepted as $p<0.05$ & & & \\
\hline
\end{tabular}

Table 3. Postoperative complications and duration of hospital stay

\begin{tabular}{|c|c|c|c|}
\hline & $\begin{array}{l}\text { Non-pandemic period } \\
(n=70)\end{array}$ & $\begin{array}{l}\text { Pandemic period } \\
(\mathrm{n}=48)\end{array}$ & $\mathbf{p}$ \\
\hline Postoperative complications & $3(4.3 \%)$ & $2(4.2 \%)$ & 0.935 \\
\hline Hospital stay (hour)* & $\begin{array}{l}48.4 \pm 33.2 \\
(\max .168)\end{array}$ & $\begin{array}{l}69.8 \pm 56.2 \\
(\max .301)\end{array}$ & 0.017 \\
\hline
\end{tabular}

Early postoperative complications developed in three patients during the non-pandemic period (wound infection in two patients and postoperative intra-abdominal abscess in one patient). During the pandemic period, early postoperative wound infection developed in two patients. No significant difference was found between the periods in terms of complications. The hospital stay was significantly longer during the pandemic period ( $p=0.017$ ) (Table 3).

The overall negative appendectomy rate was $12.7 \%$, and no significant difference was found between the pandemic $(n=5$, $10.4 \%)$ and non-pandemic $(n=10,14.3 \%)$ periods $(p=0.475)$. Two of five patients with negative appendectomy during the pandemic period tested positive for COVID-19.

The first patient preoperatively diagnosed with COVID-19 following nasopharyngeal swab test was a 15-year-old male patient. He was admitted to the paediatric emergency department with fever (tympanic, $39.2{ }^{\circ} \mathrm{C}$ ), diarrhea, vomiting and continuous right abdominal pain for 3 days. There was no suspicious history of exposure to COVID-19 or respiratory symptoms and signs. Increased levels of C-reactive protein (up to $204 \mathrm{mg} / \mathrm{L}$ ) and D-dimer $(1.5 \mathrm{\mu g} / \mathrm{mL}$ ) were detected. Preoperative chest $X$-ray findings were normal. The abdominopelvic US revealed an inflamed appendix $(8 \mathrm{~mm}$ diameter) without abscess.

The second patient was a 13-year-old boy. He was admitted to the paediatric emergency department with fever (tympanic, $39.7{ }^{\circ} \mathrm{C}$ ), vomiting and continuous right abdominal pain for $24 \mathrm{~h}$. Leukopenia $\left(3.7 \times 10^{3} \mu \mathrm{L}\right)$, lymphopaenia $\left(0.6 \times 10^{3} \mu \mathrm{L}\right)$ and increased level of D-dimer $(2.7 \mu \mathrm{g} / \mathrm{mL})$ were detected. Other routine laboratory parameters were normal. The patient had no suspicious history of exposure to COVID-19 or respiratory symptoms and signs. Preoperative chest X-ray findings were normal. The abdominopelvic US showed an inflamed appendix (11 mm diameter) with abscess and periappendiceal heterogeneity.

These two patients with COVID-19 tolerated oral feeding the day after the operation and were discharged on postoperative day 5 with home isolation precautions. No postoperative complications were observed. Histopathologic examination of the appendix showed lymphoid hyperplasia in both patients. 
These patients had abundant intraperitoneal serous fluid during operation.

\section{Discussion}

During the COVID-19 pandemic, efforts to reduce the number of elective operations have been instituted to minimize the exposure of healthcare workers and patients to COVID-19. Appendicitis was the most common surgical pathology encountered in the paediatric emergency department. During the pandemic period, the number of patients evaluated with a preliminary diagnosis of appendicitis decreased by $31 \%$. Results of analysis by age and gender during the pandemic were not significantly different from the same period of the previous year.

During the pandemic period, the incidence of complicated appendicitis is increased from $14.3 \%$ to $33.3 \%$, and open appendectomy rates increased from $4.2 \%$ to $20.8 \%$. Additionally, the hospital stay of the patients was prolonged by approximately $44.2 \%$. The triggering factor for these three conditions was the prolonged duration of symptoms. The duration of symptoms was prolonged approximately twofold during the pandemic. We think that the main factors in this delay were quarantine and stay-at-home orders, social isolation measures and fear of COVID-19 contamination in hospitals.

In this study, the effect of the COVID-19 pandemic on the diagnostic value of conventional diagnostic methods was evaluated. Classic diagnostic methods used in childhood appendicitis are history assessment, physical examination, laboratory analysis, radiological imaging and scoring systems. ${ }^{7}$ Patients with fever, nausea or vomiting and migration of pain were significantly high during the pandemic. In this study, usage of PAS is more effective during the pandemic period owing to the prolonged duration of symptoms and advanced disease stage. Diagnostic sensitivity of the abdominopelvic US was higher during the pandemic period (84\%). Additionally, secondary US findings of appendicitis (appendicolitis, free fluid and peri-appendiceal fat stranding) increased during the pandemic.

During the pandemic, we had to partly switch the operative treatment from laparoscopic approach to open surgery in patients with appendicitis. The main reasons for this conversion were the presence of COVID-19 infection and more complicated appendicitis cases with prolonged duration of symptoms. Despite this switch, we did not find a significant difference between early postoperative complication rates. In patients treated laparoscopically, we used the SPICES method to minimise air leakage from the port sites. Despite a few reports that the virus could not be found in the peritoneal fluids of patients with COVID-19, 8,9 especially during laparoscopy, ${ }^{9}$ precautions such as reduced insufflation and increased suction of the trocar site are recommended. The present study showed that, in the absence of COVID-19, a laparoscopic appendectomy can be performed safely for paediatric appendicitis cases.

COVID-19 infection can be an influential factor in the decisionmaking for paediatric appendicitis. COVID-19 infects cells with angiotensin-converting enzyme 2 (ACE2) receptors. ${ }^{10}$ ACE2 receptors have been shown to be expressed on small intestinal epithelial cells, ${ }^{11}$ and this may explain the gastrointestinal symptoms in viral infections with foecal-oral transmission. ${ }^{12}$ Most children with COVID-19 show mild clinical manifestations and recover within 1-2 weeks after disease onset. ${ }^{12}$ Recently, reports on a gastrointestinal symptoms of COVID-19 have been published. ${ }^{10,12-14}$ In the present study, two (4.2\%) patients with COVID-19 underwent surgery due to a preliminary diagnosis of acute appendicitis. Although many diagnostic parameters indicated acute appendicitis, the appendices were not macroscopically or histopathologically concordant with appendicitis. COVID-19 infection can mimic acute appendicitis. COVID-19 infection should be considered in the differential diagnosis of paediatric appendicitis cases.

\section{Study Limitations}

This study has some limitations. First, data were obtained from a single institution. Thus, nationwide prospective studies are needed for the evaluation of late presentation of paediatric appendicitis cases to emergency departments. Second, a time-matched control group was not employed.

\section{Conclusion}

The COVID-19 pandemic has vital influence on emergency health services. Although there was a worldwide decrease in admission to the emergency department during this period, urgent surgical cases have presented with more advanced clinical conditions. The major concern for healthcare professionals and patients is to prevent contact with COVID-19 cases at any stage by providing rapid diagnosis and treatment practices. During the COVID-19 pandemic, fewer patients with suspected appendicitis presented to the paediatric emergency department. Complicated appendicitis cases and hospital stay increased during the same period.

COVID-19 pandemic caused some changes in our approach to paediatric appendicitis cases such as effective use of personal protective equipment, PAS scoring system and abdominopelvic US. Additionally, liberal use of open appendectomy has been determined. 


\section{Ethics}

Ethics Committee Approval: The study was approved by Dokuz Eylül University Faculty of Medicine 5639-GOA2020/18-19.

Informed Consent: Informed consent was not obtained from the patients given the retrospective study design.

Peer-review: Externally peer-reviewed.

\section{Authorship Contributions}

Conception: O.U., O.A., M.O., Design: O.U., O.Z.K., O.A., M.O., G.H., Data Collection or Processing: O.U., E.A., Analysis or Interpretation: O.U., O.Z.K., M.O., G.H., Literature Search: O.U., O.A., G.H., F.M.A., Writing: O.U., O.Z.K., O.A., F.M.A..

Conflict of Interest: No conflict of interest was declared by the authors.

Financial Disclosure: The authors declared that this study received no financial support.

\section{References}

1. World Health Organization WHO timeline- COVID-19. Available athttps://www.who.int/news-room/detailed/27-04-2020-whotimeline-covid-19. Accessed September 14, 2020.

2. Cucinotta D, Vanelli M. WHO Declares COVID-19 a Pandemic. Acta Biomed. 2020;91:157-60.

3. Lazzerini M, Barbi E, Apicella A, Marchetti F, Cardinale F, et al. Delayed access or provision of care in Italy resulting from fear of COVID-19. Lancet Child Adolesc Health. 2020;4:10-1.
4. Glass CC, Rangel SJ. Overview and diagnosis of acute appendicitis in children. Semin Pediatr Surg. 2016;25:198-203.

5. Samuel M. Pediatric appendicitis score. J Pediatr Surg. 2002;37:87781.

6. Akgür FM, Olguner M, Hakgüder G, Ateş O. Appendectomy conducted with Single Port Incisionless-Intracorporeal Conventional Equipment-Endoscopic Surgery. J Pediatr Surg. 2010;45:1061-3.

7. Stringer MD. Acute appendicitis. J Paediatr Child Health. 2017;53:1071-6.

8. Vudayagiri L, Gusz J. COVID-19 Positive in Nasopharyngeal Swab but Negative in Peritoneal Fluid: Case Report of Perforated Appendicitis. Cureus. 2020;12:9412.

9. Ngaserin $\mathrm{SH}$, Koh FH, Ong BC, Chew MH. COVID-19 not detected in peritoneal fluid: a case of laparoscopic appendicectomy for acute appendicitis in a COVID-19-infected patient. Langenbecks Arch Surg. 2020;405:353-5.

10. Zhou $P$, Yang $X L$, Wang $X G$, Hu B, Zhang $L$, et al. A pneumonia outbreak associated with a new coronavirus of probable bat origin. Nature. 2020;579:270-3.

11. Hamming I, Timens W, Bulthuis ML, Lely AT, Navis G, et al. Tissue distribution of ACE2 protein, the functional receptor for SARS coronavirus. A first step in understanding SARS pathogenesis. J Pathol. 2004;203:631-7.

12. Cai $X, M a Y, L i S$, Chen $Y$, Rong $Z$, et al. Clinical Characteristics of 5 COVID-19 Cases With Non-respiratory Symptoms as the First Manifestation in Children. Front Pediatr. 2020;8:258.

13. Ashcroft J, Hudson VE, Davies RJ. COVID-19 gastrointestinal symptoms mimicking surgical presentations. Ann Med Surg (Lond). 2020;56:108-9.

14. Suwanwongse K, Shabarek N. Pseudo-Appendicitis in an Adolescent With COVID-19. Cureus. 2020;12:9394. 